\title{
Neisseria cinerea in a Post-splenectomy Patient: A Rare Potentially Fatal Bacteremia
}

Ravikaran Patti ${ }^{1}$, Sushilkumar S. Gupta ${ }^{2}$, Sharonlin Bhardwaj ${ }^{3}$, Prameeta Jha ${ }^{1}$, Arindam Ghatak $^{4}$, Yizhak Kupfer ${ }^{2}$, Chanaka Seneviratne ${ }^{5}$

1. Internal Medicine, Maimonides Medical Center, Brooklyn, USA 2. Critical Care, Maimonides Medical Center, Brooklyn, USA 3. Internal Medicine, Maimonides, Brooklyn, USA 4. Department of Critical Care Medicine, Maimonides Medical Center, Brooklyn, USA 5. Pulmonary and Critical Care, Maimonides Medical Center, Brooklyn, USA

$\square$ Corresponding author: Ravikaran Patti,dr.ravikaran@gmail.com

Disclosures can be found in Additional Information at the end of the article

\section{Abstract}

Neisseria cinerea is a commensal which usually resides in the human respiratory tract. Very rarely, the organism finds its way into the bloodstream causing severe bacteremia. So far, very few cases of Neisseria bacteremia have been reported. We report a case of a 78-year-old male, post-splenectomy, who presented with high fever, cough and shortness of breath. The patient was initially managed for septic shock with fluid resuscitations, vasopressors and broad-spectrum antibiotics. Later, the blood cultures grew gram-negative coccobacilli, Neisseria cinerea. The patient was successfully treated with intravenous ceftriaxone. This is the first case ever of Neisseria cinerea bacteremia in a post-splenectomy patient and ninth case overall. This case illustrates that the physicians should maintain heightened awareness for Neisseria cinerea bacteremia in post-splenectomy patients.

Categories: Internal Medicine, Infectious Disease

Keywords: neisseria cinerea, bacteremia, post splenectomy patient

\section{Introduction}

Neisseria cinerea is a non-pathogenic, gram-negative, catalase-positive and oxidase-positive diplococci [1]. It is an asaccharolytic commensal Neisseria species which usually resides in the upper respiratory tract but sometimes finds its way to bloodstream causing a life-threatening infection. Most of the patients reported with Neisseria cinerea bacteremia have some form of immunodeficiency, while a few were completely healthy. Identifying Neisseria cinerea is a

Received 07/07/2018

Review began 07/12/2018 Review ended 07/16/2018 Published 07/19/2018

C) Copyright 2018

Patti et al. This is an open access article distributed under the terms of the Creative Commons Attribution License CC-BY 3.0., which permits unrestricted use, distribution, and reproduction in any medium, provided the original author and source are credited. challenge for microbiologists as it shares both biochemical and morphological characteristics with Neisseria gonorrhea and Branhamella catarrhalis [1]. We report first ever case of Neisseria cinerea bacteremia in a post-splenectomy patient rather than the usual encapsulated organisms.

\section{Case Presentation}

A 78-year-old male presented to the emergency room with complains of high fever, and nonbloody non-bilious vomiting. This was associated with a non-productive cough and dyspnea. He had a past medical history of splenectomy following thrombotic thrombocytopenic purpura (TTP) and recurrent pneumonia. On presentation, the patient was febrile to $101.7^{\circ} \mathrm{F}$, respiratory rate of 34 breaths per minute and blood pressure of 83/49 mm Hg. Complete blood 


\section{Cureus}

count showed leukopenia with white cell count of $1.1 \times 10^{9}$ per liter (L), bandemia of $27 \%$ and lactic acidosis of $12.3 \mathrm{mmol} / \mathrm{l}$ on the venous blood gas. Computed tomography (CT) scan of the chest/abdomen, and pelvis with oral contrast was performed which showed consolidation in the left lower lobe of lung (Figure 1).

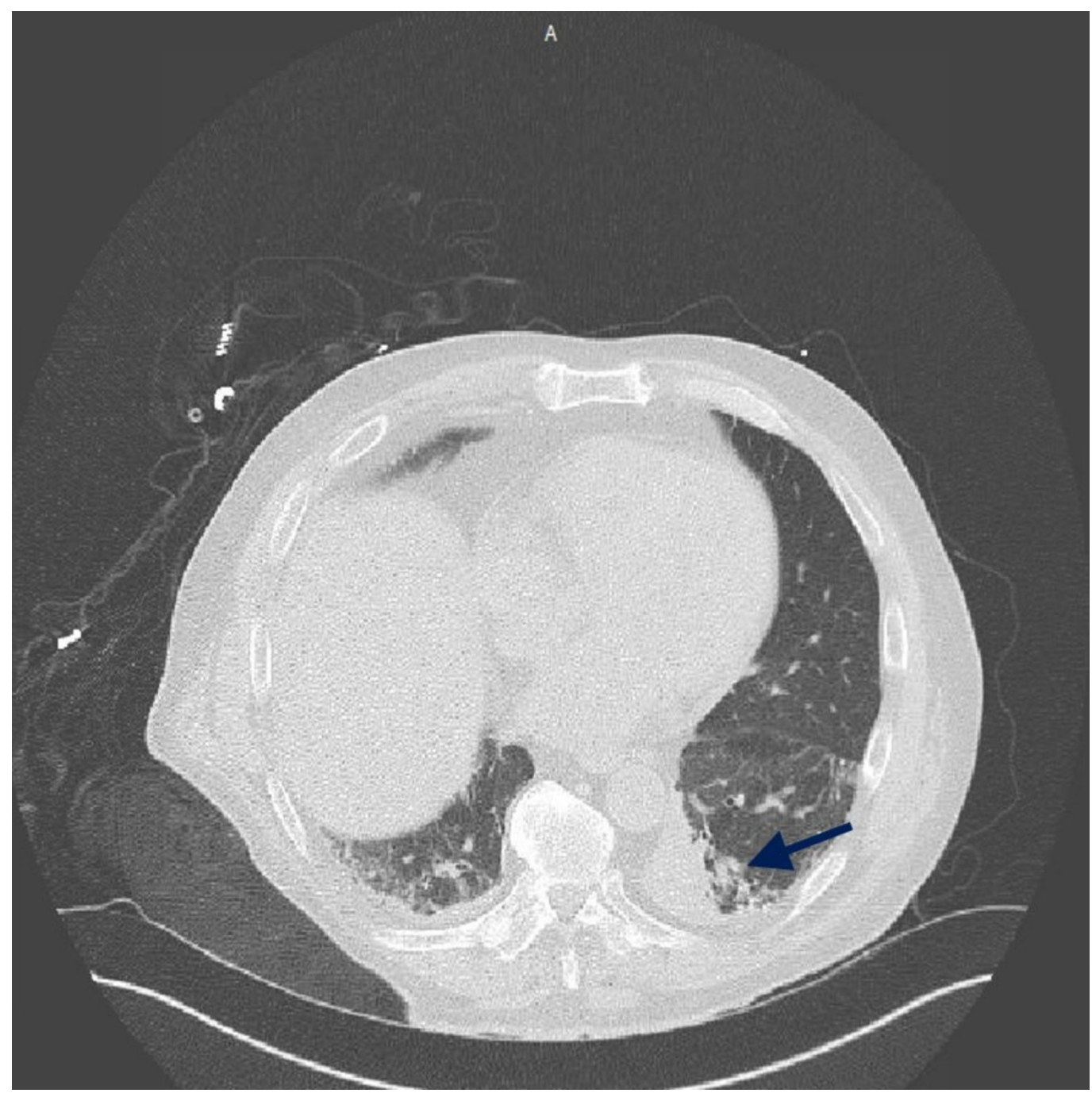

FIGURE 1: Computed tomography scan of the chest showing consolidation within medial portion of the left lower lobe (blue arrow).

The patient was admitted in the medical intensive care unit with the preliminary diagnosis of severe sepsis with septic shock. Sequential organ failure assessment (SOFA) score at the time of admission was 10. Sepsis bundle was initiated and intravenous (IV) crystalloid resuscitation at $30 \mathrm{ml} / \mathrm{kg}$ was immediately started, blood cultures were drawn and intravenous broad-spectrum antibiotics were initiated. Due to inadequate response to intravenous fluids, a vasopressor agent (phenylephrine) and stress dose steroid (hydrocortisone) was started. Blood cultures grew gram-negative coccobacilli, Neisseria species which was later confirmed by microbiologist as Neisseria cinerea. Antibiotics were narrowed down to IV ceftriaxone 2 gm every 12 hours based on the sensitivity.

During the course of hospitalization, the patient improved clinically and remained 
hemodynamically stable. Repeat blood cultures did not show any growth and the patient was discharged home after completion of two weeks of intravenous ceftriaxone.

\section{Discussion}

Neisseria cinerea was first identified in 1905 as Micrococcus cinereus by Alexander von Lingelsheim [2]. In 1962, Berger and Paepcke described it to be an asaccharolytic commensal of the human oropharynx which was later described correctly as a commensal of human oropharynx and sometimes of the urogenital tract by Knapp et al. in 1984 [2-3]. N. cinerea is an oxidase-positive and catalase-positive, gram-negative diplococci. The bacteria share many morphological and biochemical similarities with Neisseria gonorrhea and Branhamella catarrhalis. Neisseria cinerea is able to reduce glucose like N. gonorrhea but not able to utilize it for energy, making it asaccharolytic. Amino acids like cysteine, cystine, proline and arginine are required for its growth. Unlike Neisseria gonorrhea, $N$. cinerea can grow on mediums like Mueller-Hinton agar and trypticase soy agar, and is not resistant to colistin [4].

As described earlier, Neisseria cinerea normally colonizes human oropharynx but very rarely enters the bloodstream. All the cases of N. cinerea bacteremia reported to date are described in Table $1[1,4-9]$. 


\section{Cureus}

\begin{tabular}{|c|c|c|c|c|c|c|c|}
\hline Patient & $\begin{array}{l}\text { Age } \\
\text { (years) }\end{array}$ & Comorbidities & $\begin{array}{l}\text { Risk of } \\
\text { infection }\end{array}$ & $\begin{array}{l}\text { Additional } \\
\text { infection }\end{array}$ & Antibiotics given & Outcome & Reference \\
\hline 1. & 59 & $\begin{array}{l}\text { Myelodysplastic } \\
\text { syndrome }\end{array}$ & Chemotherapy & None & Imipenem for 14 days & Died & $\begin{array}{l}\text { Zhu et al. } \\
\text { [1] }\end{array}$ \\
\hline 2. & 58 & $\begin{array}{l}\text { Multiple sclerosis - } \\
\text { Severe Trigeminal } \\
\text { neuralgia }\end{array}$ & $\begin{array}{l}\text { Percutaneous } \\
\text { glycerol } \\
\text { rhizotomy }\end{array}$ & Meningitis & $\begin{array}{l}\text { Ceftriaxone for seven } \\
\text { days }\end{array}$ & Survived & $\begin{array}{l}\text { Von Kietzell } \\
\text { et al. [5] }\end{array}$ \\
\hline 3. & 47 & $\begin{array}{l}\text { End-stage renal } \\
\text { disease (ESRD) on } \\
\text { hemodialysis }\end{array}$ & $\begin{array}{l}\text { Coughing onto } \\
\text { arteriovenous } \\
\text { graft site }\end{array}$ & None & Ciprofloxacin & Survived & $\begin{array}{l}\text { Johnson et } \\
\text { al. [6] }\end{array}$ \\
\hline 4. & 46 & Alcohol abuse & None & $\begin{array}{l}\text { Acute } \\
\text { abdomen } \\
\text { with } \\
\text { bacteremia }\end{array}$ & $\begin{array}{l}\text { Tobramycin, clindamycin, } \\
\text { vancomycin, piperacillin, } \\
\text { cefoxiti, ampicillin, } \\
\text { amikacin and cefotaxime }\end{array}$ & Died & $\begin{array}{l}\text { Southern \& } \\
\text { Kutscher } \\
{[7]}\end{array}$ \\
\hline 5. & 2.5 & $\begin{array}{l}\text { Frequent upper } \\
\text { respiratory tract } \\
\text { infections }\end{array}$ & None & $\begin{array}{l}\text { Otitis media } \\
\text { and } \\
\text { pneumonia }\end{array}$ & Amoxicillin for 10 days & Survived & $\begin{array}{l}\text { Southern \& } \\
\text { Kutscher } \\
{[7]}\end{array}$ \\
\hline 6. & 34 & Intravenous drug use & $\begin{array}{l}\text { Intravenous } \\
\text { drug use }\end{array}$ & $\begin{array}{l}\text { Tricuspid } \\
\text { valve } \\
\text { endocarditis }\end{array}$ & $\begin{array}{l}\text { Co-amoxiclav, ceftriaxone } \\
\text { and amoxicillin }\end{array}$ & Survived & $\begin{array}{l}\text { Benes et al. } \\
\text { [8] }\end{array}$ \\
\hline 7. & 17 & None & $\begin{array}{l}\text { Facial trauma } \\
\text { with laxation } \\
\text { of two teeth }\end{array}$ & Meningitis & Cefotaxime & Survived & $\begin{array}{l}\text { Kirchgesner } \\
\text { et al. [9] }\end{array}$ \\
\hline 8. & 38 & $\begin{array}{l}\text { Postpartum } \\
\text { Hemolytic-uremic } \\
\text { Syndrome (HUS) } \\
\text { causing ESRD }\end{array}$ & Eculizumab & None & Cefepime & Survived & $\begin{array}{l}\text { Walsh et al. } \\
{[4]}\end{array}$ \\
\hline 9. & 78 & $\begin{array}{l}\text { Post splenectomy } \\
\text { and Thrombotic } \\
\text { Thrombocytopenic } \\
\text { purpura }\end{array}$ & $\begin{array}{l}\text { Post } \\
\text { splenectomy }\end{array}$ & $\begin{array}{l}\text { Left lower } \\
\text { lobe } \\
\text { pneumonia }\end{array}$ & Ceftriaxone & Survived & $\begin{array}{l}\text { Current } \\
\text { case }\end{array}$ \\
\hline
\end{tabular}

TABLE 1: Table listing all reported cases of Neisseria cinerea.

Our case is the first case of a patient who had undergone splenectomy, who developed Neisseria cinerea bacteremia reported in the literature. Usually, in such patients, encapsulated organisms such as Streptococcus pneumoniae, Haemophilus influenzae or Neisseria meningitidis are the common causes of infection. Immune deficiency was common in most of the previously described cases, and can be considered as the most vital cause leading to bacteremia. Recent reports have demonstrated that despite the use of appropriate vaccination, these immunocompromised patients are still at increased risk of infection with Neisseria bacteremia [10]. 


\section{Conclusions}

By reporting this case we recommend that Neisseria cinerea bacteremia should be considered in the differential diagnosis of post-splenectomy patients causing infection. A clear understanding of how Neisseria cinerea, an unusual non-encapsulated organism, causes overwhelming sepsis in a post-splenectomy patient, needs further workup. One should also be very cautious in properly isolating Neisseria cinerea due to rarity and similarities with N. gonorrhea.

\section{Additional Information}

\section{Disclosures}

Human subjects: Consent was obtained by all participants in this study. Not applicable issued approval Not applicable. Conflicts of interest: In compliance with the ICMJE uniform disclosure form, all authors declare the following: Payment/services info: All authors have declared that no financial support was received from any organization for the submitted work. Financial relationships: All authors have declared that they have no financial relationships at present or within the previous three years with any organizations that might have an interest in the submitted work. Other relationships: All authors have declared that there are no other relationships or activities that could appear to have influenced the submitted work.

\section{References}

1. Zhu X, Li M, Cao H, Yang X: Fatal bacteremia by Neisseria cinerea in a woman with myelodysplastic syndrome: a case report. Int J Clin Exp Med. 2015, 8:6369-6371.

2. Berger U, Paepcke E: Studies on asaccharolytic Neisseria in the human nasopharynx (Article in German). Z Hyg Infektionskr. 1962, 148:269-281.

3. Knapp JS, Totten PA, Mulks MH, Minshew BH: Characterization of Neisseria cinerea, a nonpathogenic species isolated on Martin-Lewis medium selective for pathogenic Neisseria spp.. J Clin Microbiol. 1984, 19:63-67.

4. Walsh TL, Bean HR, Kaplan RB: Neisseria cinerea bacteremia in a patient receiving eculizumab: a case report. Infection. 2018, 46:271-274. 10.1007/s15010-017-1090-4

5. Von Kietzell M, Richter H, Bruderer T, Goldberger D, Emonet S, Strahm C: Meningitis and bacteremia due to Neisseria cinerea following a percutaneous rhizotomy of the trigeminal ganglion. J Clin Microbiol. 2016, 54:233-235. 10.1128/JCM.02041-15

6. Johnson DH, Febre E, Schoch PE, Imbriano L, Cunha BA: Neisseria cinerea bacteremia in a patient receiving hemodialysis. Clin Infect Dis. 1994, 19:990-991. 10.1093/clinids/19.5.990

7. Southern PM Jr, Kutscher AE: Bacteremia due to Neisseria cinerea: report of two cases . Diagn Microbiol Infect Dis. 1987, 7:143-147. 10.1016/0732-8893(87)90032-0

8. Benes J, Dzupova O, Krizova P, Rozsypal H: Tricuspid valve endocarditis due to Neisseria cinerea. Eur J Clin Microbiol Infect Dis. 2003, 22:106-107. 10.1007/s10096-002-0874-2

9. Kirchgesner V, Plesiat P, Dupont MJ, Estavoyer JM, Guibour-denche M, Riou JY, Michel-Briand Y: Meningitis and septicemia due to Neisseria cinerea . Clin Infect Dis. 1995, 21:1351. 10.1093/clinids/21.5.1351

10. McNamara LA, Topaz N, Wang X, Hariri S, Fox L, MacNeil JR: High risk for invasive meningococcal disease among patients receiving eculizumab (Soliris) despite receipt of meningococcal vaccine. MMWR Morb Mortal Wkly Rep. 2017, 66:734-737.

10.15585/mmwr.mm6627e1 